\title{
Analysis of Streamflow and Water-Quality Data at Two Long-Term Monitoring Sites on the St. Croix River, Wisconsin and Minnesota
}

\begin{abstract}
Streamflow of the St. Croix River has been monitored on a long-term basis by the U.S. Geological Survey (USGS) at streamflow-gaging stations on the St. Croix River at Wisconsin State Highway 35 near Danbury, Wisconsin and below the dam at St. Croix Falls, Wisconsin. Trend analysis indicates that annual streamflow peaks, annual mean flows, and annual 7-day low flows have remained relatively stable at the Danbury (upstream) station from 1914 to 2001 but have increased by 0.45 to 0.55 percent per year at the St. Croix Falls (downstream) station from 1902 to 2001.
\end{abstract}

Water-quality sampling conducted by the USGS at two associated water-quality monitoring sites from 1964 to 2001 have included analysis for nutrients, suspended sediments, metals, bacteria, and pesticides. The water-quality data at the two sites had considerable temporal variation and was often limited in extent by the data-collection needs of previous projects. The absence of consistent long-term water-quality data made detection of statistically significant trends in the water-quality data difficult. Nutrient, suspended-sediment, and major ion concentrations and field parameters were generally higher and more variable at the St. Croix Falls site than at the Danbury site. However, disparate sampling periods and strategies could cause possible biases in the comparison of water quality between sites.

\section{Introduction}

The U.S. Geological Survey (USGS) has performed long-term continuous streamflow measurements of the St. Croix River at two streamflow-gaging stations: at Wisconsin State Highway 35 near Danbury, Wisconsin and below the dam at St. Croix Falls, Wisconsin (fig. 1). Water-quality measurements of a variety of constituents such as nutrients, suspended sediments, metals, bacteria, and pesticides have been collected at two water-quality monitoring sites associated with these streamflow-gaging stations. This report will refer to both the streamflow-gaging stations and associated water-quality monitoring sites as sites.

This study, which was initiated in 2001, was a cooperative effort between the USGS, National Park Service (NPS), and the Joint Water Quality Commission of Danbury and St. Croix Chippewa Indians of Wisconsin to analyze the long-term USGS flow data for temporal trends and provide summaries and analysis of the USGS water-quality data collected at these sites. This report presents trends in flow and differences in water quality among sites, studies, and over time. Streamflow data from 1902 to 2001 and water-quality data from 1964 to 2001 are included in this study.

Differences between the long-term data sets can be used to determine the part of the St. Croix River Basin where change has occurred. Trends at the Danbury site reflect changes in the upper basin (1,580 square miles), trends in the difference between the St. Croix Falls and Danbury sites reflect changes that occurred in the part of the drainage basin between those two sites (4,660 square miles), and trends at the St. Croix Falls

Figure 1. Long-term monitoring sites on the St. Croix River, Wisconsin and Minnesota.

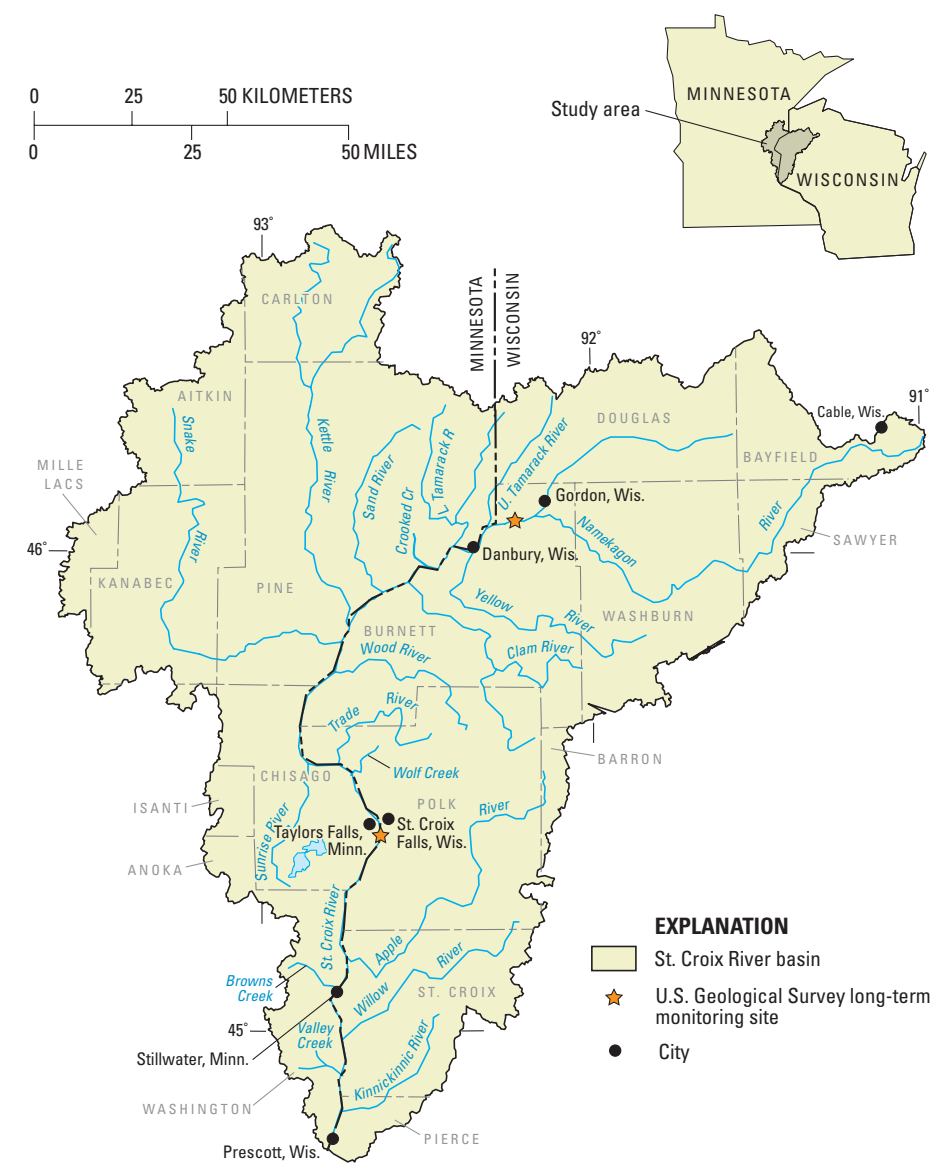

Base map: Seaber and others, 1986

Access data online at http://wi.waterdata.usgs.gov/nwis 
site reflect changes in the entire drainage basin upstream of that site (6,240 square miles). U.S. Census data were used to depict population change by decade in the St. Croix Basin.

\section{Streamflow}

St. Croix River streamflow monitoring by the USGS has taken place at the streamflow-gaging station at Wisconsin State Highway 35 near Danbury since 1914 (with the exception of October 1981 to September 1984 when the site was not maintained) and at the streamflow-gaging station below the dam at St. Croix Falls since 1902. Flows at both sites are affected by regulation. The statistics and trends presented in this report include the impacts of that regulation.

Individual flow rates in cubic feet per second $\left(\mathrm{ft}^{3} / \mathrm{s}\right)$ are determined at 15-minute or 1-hour intervals. The highest 15-minute flow value (peak instantaneous) at each site occurred in April 2001 with the river flowing at $11,000 \mathrm{ft}^{3} / \mathrm{s}$ at the Danbury site and $60,900 \mathrm{ft}^{3} / \mathrm{s}$ at the St. Croix Falls site. Individual 15-minute or 1-hour flow values are averaged over each day to determine the daily mean flow. Daily mean flow statistics for the Danbury and St. Croix Falls sites over the periods of record are presented in table 1 . Daily mean flows at the Danbury site ranged from 405 to $10,600 \mathrm{ft}^{3} / \mathrm{s}$. Daily mean flows were more variable at the St. Croix Falls site, ranging from 75 to $59,500 \mathrm{ft}^{3} / \mathrm{s}$.

Annual flow statistics for the two sites are presented in table 2. Annual mean flow was computed by averaging mean daily flows for the period from October 1st to September 30th of each water year of record. Annual mean flows ranged from 795 to $1,982 \mathrm{ft}^{3} / \mathrm{s}$ at the Danbury site and were more variable at the St. Croix Falls site, ranging from 1,754 to $8,569 \mathrm{ft}^{3} / \mathrm{s}$. The average annual mean flows for the periods of record differ by 3,067 $\mathrm{ft}^{3} / \mathrm{s}$ between sites. Annual mean flows differ by as little as 959 $\mathrm{ft}^{3} / \mathrm{s}$ in the driest year (1934) and as much as $6,587 \mathrm{ft}^{3} / \mathrm{s}$ in the wettest year (1984). The highest mean daily flow calculated annually (peak daily) and averaged for the periods of record was about five times lower at the Danbury site $\left(4,898 \mathrm{ft}^{3} / \mathrm{s}\right)$ than at the St. Croix Falls site $\left(24,000 \mathrm{ft}^{3} / \mathrm{s}\right)$.
Table 1. Daily mean flow statistics for the Danbury and St. Croix Falls, Wis., streamflow-gaging stations on the St. Croix River, Wis. and Minn., 1902-2001

$\left[\mathrm{ft}^{3} / \mathrm{s}\right.$, cubic feet per second]

\begin{tabular}{lcc}
\hline & Danbury $\left(\mathbf{f t}^{3} \mathbf{s}\right)$ & St. Croix Falls $\left(\mathbf{f t}^{3} \mathbf{s}\right)$ \\
\hline Maximum & 10,600 & 59,500 \\
10 percent exceeds & 2,190 & 9,020 \\
50 percent exceeds & 1,080 & 2,800 \\
90 percent exceeds & 730 & 1,580 \\
Minimum & 405 & 75 \\
\hline
\end{tabular}

Low flows were defined as the minimum average mean daily flow for 7 consecutive days within a water year (7-day low flow). The minimum 7-day low flow for the period of record occurred in July 1934 at the Danbury site $\left(417 \mathrm{ft}^{3} / \mathrm{s}\right)$ and in August 1934 at the St. Croix Falls site $\left(754 \mathrm{ft}^{3} / \mathrm{s}\right)$. The average annual 7-day low flow at the Danbury site $\left(731 \mathrm{ft}^{3} / \mathrm{s}\right)$ was about one-half that at the St. Croix Falls site $\left(1,620 \mathrm{ft}^{3} / \mathrm{s}\right)$ for the periods of record.

Trend analysis was performed on the annual long-term USGS flow data from each site, and on the difference in the flow between the two sites using a Kendall's Tau test (Kendall, 1975; Conover, 1971) and linear regression analysis. The Kendall test is a nonparametric test of the strength of a trend and is appropriate for data that are not normally distributed. Linear regression analyses were performed to quantify the amount of change, if a statistically significant trend existed. Ten-year moving averages were calculated by taking the mean of the previous ten years of data; thus, each new year's numbers are added to the average and the oldest numbers are dropped so that the average "moves" over time. The moving average demonstrates shorter-term changes in flow over the period of record. Trend analyses were performed on four annual streamflow statistics: peak instantaneous, peak daily, mean, and 7-day low flow (table 3, fig. 2).

Table 2. Annual flow statistics for the Danbury and St. Croix Falls, Wis., streamflow-gaging stations on the St. Croix River, Wis. and Minn., 1902-2001

$\left[\mathrm{ft}^{3} / \mathrm{s}\right.$, cubic feet per second]

\begin{tabular}{|c|c|c|c|c|c|c|c|}
\hline Site & $\begin{array}{c}\text { Drainage } \\
\text { area }\end{array}$ & $\begin{array}{l}\text { Years of } \\
\text { record }\end{array}$ & & $\begin{array}{c}\text { Peak } \\
\text { instantaneous } \\
\left(\mathrm{ft}^{3} / \mathbf{s}\right)\end{array}$ & $\begin{array}{l}\text { Peak daily } \\
\quad\left(\mathrm{ft}^{3} / \mathrm{s}\right)\end{array}$ & $\begin{array}{l}\text { Mean } \\
\left(\mathrm{ft}^{3} / \mathrm{s}\right)\end{array}$ & $\begin{array}{l}\text { 7-day } \\
\text { low flow } \\
\left(\mathrm{ft}^{3} / \mathrm{s}\right)\end{array}$ \\
\hline Danbury & 1,580 & $\begin{array}{c}1914- \\
2001\end{array}$ & $\begin{array}{r}\text { Mean: } \\
\text { Maximum: } \\
\text { Minimum: }\end{array}$ & $\begin{array}{r}5,055 \\
11,000(\text { on } 4 / 24 / 2001) \\
2,030(\text { on } 4 / 17 / 1926)\end{array}$ & $\begin{array}{l}4,898 \\
10,600 \text { (in 2001) } \\
2,030(\text { in } 1926)\end{array}$ & $\begin{array}{l}1,320 \\
1,982(\text { in } 1986) \\
795(\text { in } 1934)\end{array}$ & $\begin{array}{r}731 \\
1,171 \text { (in Feb. 1986) } \\
417 \text { (in July 1934) }\end{array}$ \\
\hline St. Croix Falls & 6,240 & $\begin{array}{l}1902- \\
2001\end{array}$ & $\begin{array}{r}\text { Mean: } \\
\text { Maximum: } \\
\text { Minimum: }\end{array}$ & $\begin{array}{l}24,400 \\
60,900(\text { on } 4 / 24 / 2001) \\
6,820(\text { on } 10 / 01 / 1924)\end{array}$ & $\begin{array}{l}24,000 \\
59,500 \text { (in 2001) } \\
6,820 \text { (in 1924) }\end{array}$ & $\begin{array}{l}4,387 \\
8,569(\text { in } 1986) \\
1,754(\text { in } 1934)\end{array}$ & $\begin{array}{l}1,620 \\
2,806 \text { (in Feb. 1983) } \\
754 \text { (in Aug. 1934) }\end{array}$ \\
\hline $\begin{array}{l}\text { Difference } \\
\text { between sites }\end{array}$ & 4,660 & $\begin{array}{c}1914- \\
2001\end{array}$ & $\begin{array}{r}\text { Mean: } \\
\text { Maximum: } \\
\text { Minimum: }\end{array}$ & $\begin{array}{r}19,800 \\
49,900 \\
2,890\end{array}$ & $\begin{array}{r}19,255 \\
48,900 \\
4,790\end{array}$ & $\begin{array}{r}3,067 \\
6,587 \\
959\end{array}$ & $\begin{array}{r}889 \\
1,513 \\
337\end{array}$ \\
\hline
\end{tabular}


Table 3. Res

on the St. Croix River, Wis. and Minn., 1902-2001

[Highlighted data indicate values that are statistically significant at the 95-percent confidence interval, $\mathrm{p}<0.05$; $\mathrm{ft}^{3} / \mathrm{s} / \mathrm{yr}$, cubic feet per second per year]

\begin{tabular}{llrrrr}
\hline \multicolumn{1}{c}{ Site } & \multicolumn{1}{c}{$\begin{array}{c}\text { Annual flow } \\
\text { value }\end{array}$} & $\begin{array}{c}\text { Slope } \\
\left(\mathbf{f t}^{3} / \mathbf{s} / \mathbf{y r}\right)\end{array}$ & $\begin{array}{c}\text { Percent } \\
\text { change } \\
\text { per year }\end{array}$ & $\begin{array}{c}\text { Kendall's } \\
\text { Tau }\end{array}$ & Probability \\
\hline Danbury & Peak instantaneous & 15.0 & 0.30 & 0.145 & 0.070 \\
& Peak daily & 15.1 & .31 & .154 & .058 \\
& Mean & 2.7 & .20 & .163 & .017 \\
& 7-day low flow & 1.3 & .68 & .133 & .052 \\
& & & & & \\
St. Croix Falls & Peak instantaneous & 129.4 & .53 & .193 & $<.010$ \\
& Peak daily & 109.4 & .45 & .172 & .013 \\
& Mean & 24.1 & .55 & .308 & $<.010$ \\
& 7-day low flow & 8.1 & .50 & .353 & $<.010$ \\
\hline Difference & Peak instantaneous & 101.9 & .51 & .178 & .016 \\
between & Peak daily & 81.8 & .42 & .137 & .049 \\
two sites & Mean & 17.1 & .56 & .258 & $<.001$ \\
& 7-day low flow & 5.0 & .56 & .326 & $<.001$ \\
\hline
\end{tabular}

Mean annual flow was the only flow characteristic at the Danbury site that had a statistically significant (at the $95-$ percent confidence level; $\mathrm{p}<0.05)$ trend. Although significant, it only increased slowly ( 0.2 percent per year). All four annual streamflow characteristics at the St. Croix Falls site had significantly increasing trends of 0.45 to 0.55 percent per year. Trends in the difference in flow between the two sites were similar to the trends at the St. Croix Falls site. This is to be expected because the flow characteristics at the Danbury site remained relatively stable while the flow characteristics at the St. Croix Falls site increased. The trends in the difference between the two sites were also significant for all four annual streamflow characteristics.

Annual mean flows were further analyzed for trends during spring, summer, fall, and winter. No significant trends were detected in seasonal flows at the Danbury site. Significant increasing trends were detected at the St. Croix Falls site during spring, fall, and winter. The slope of the annual summer mean flow at the St. Croix Falls site was positive, but not significant at the 95-percent confidence level. Summer flows are affected by rainfall-runoff events, and thus more variable than flows during the rest of the year. This variability may mask subtle trends.

\section{Analysis of Streamflow Trends}

The trend analysis of St. Croix River annual flow data over the period of record shows peak instantaneous, peak daily, mean, and 7-day low flows have no trend or only slightly increased at the Danbury site; whereas, flows have increased at the St. Croix Falls site. Often, streamflow trends can be attributed to changes in climate; however, the St. Croix River sites are in such close proximity that climate should similarly affect flow at both sites. It is therefore likely that the increasing flows at St. Croix Falls could be attributed to factors other than climate.

Dam regulation impacts flow at both sites. The St. Croix Falls site is affected by the St. Croix Falls Dam and the Danbury site is affected by the Trego Dam. Both dams are used for electrical power generation. Permit requirements of dam operation require minimum flows be maintained during periods of regulation. When river flows drop below these minimums, regulation ceases and the river flows at run of the river conditions. Additionally, when flows are high there is more water flowing than can be used for power generation; turbines are at full capacity and excessive water still runs over the spillway, thus no regulation impacts occur. However, during periods of moderate flow, storage and release for power generation cause low flows to be lower (during storage) and high flows to be higher (during generation) than without regulation. Historical changes in reservoir operation such as required minimum flows or gate-changing procedures may have impacts on flow trends.

In addition to dam regulation, other factors have been shown to impact flow trends in Wisconsin. A study by Potter (1991) attributed increased baseflow in a stream in eastern Wisconsin to advances in farming practices that resulted in increased recharge. A streamflow-trend study by Gebert and Krug (1996) concluded that decreased flood peaks and increased annual low flows in streams from the Wisconsin Driftless Area were caused by changes in agricultural practices and land use. It has been shown that runoff characteristics are different in urban areas of Wisconsin than in agricultural or forested areas, or areas with native grassland (Hunt, 2001).

Additional study of changes in climate, operation of hydropower dams, urban growth, agricultural practices, and land use 


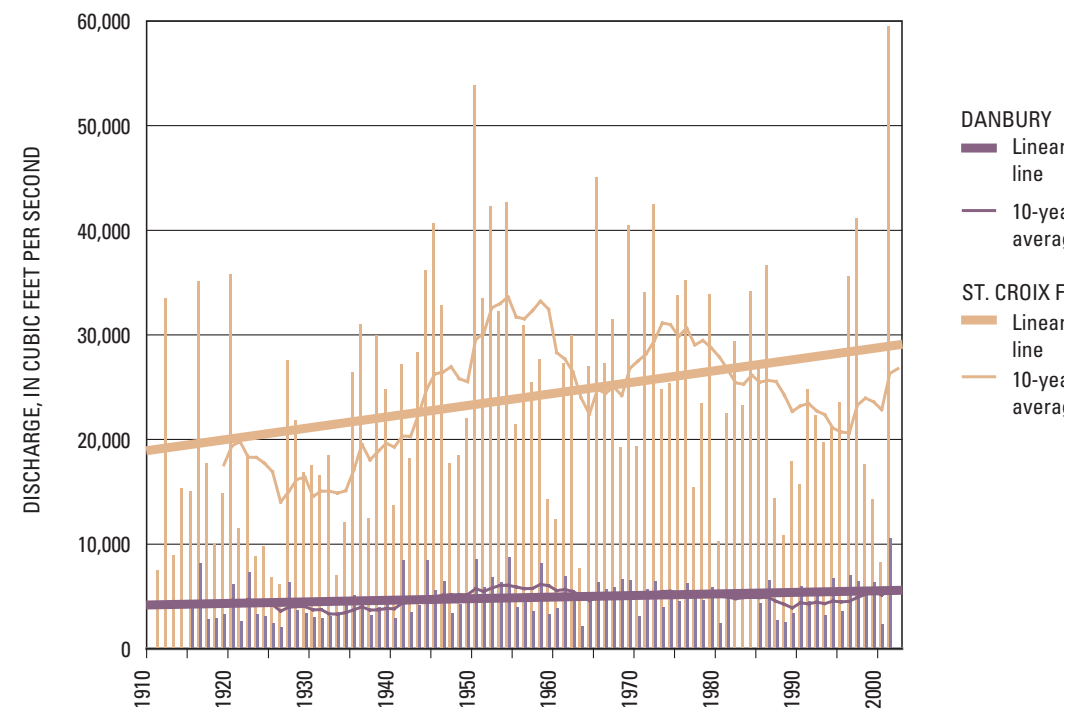

Figure 2a. Annual peak daily flows for period 1912-2001 at Danbury and St. Croix Falls, Wis. on the St. Croix River, Wis. and Minn.

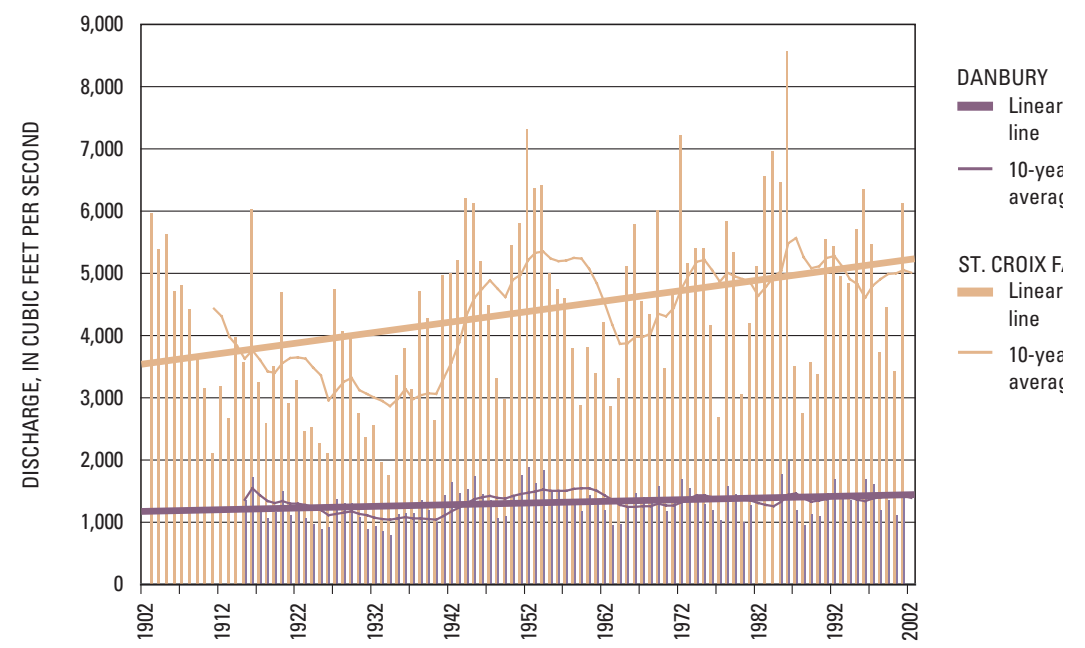

Figure 2b. Annual mean flows for period 1902-2001 at Danbury and St. Croix Falls, Wis. on the St. Croix River, Wis. and Minn.

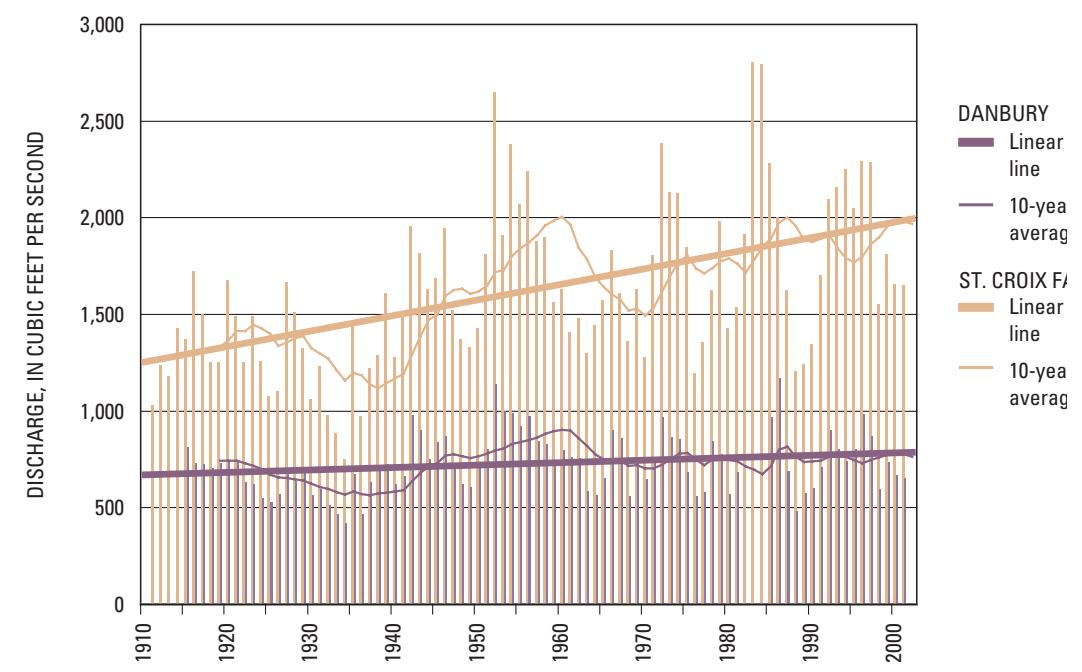

Figure 2c. Annual 7-day low flows for period 1912-2001 at Danbury and St. Croix Falls, Wis. on the St. Croix River, Wis. and Minn. would be needed to substantiate the causes of the observed flow trends.

\section{Water Quality}

The USGS water-quality database QWDATA contains 226 analyses of various water-quality constituents at the Danbury site and 343 analyses at the St. Croix Falls site. The earliest samples were suspended-sediment samples from the Danbury site in 1964 and nitrate samples from the St. Croix Falls site in 1966. Most of the data were collected in the mid1970s and early 1980s, and from 1995 to 2001. The major water-quality studies conducted by the USGS at these sites include: a 1975-83 water-quality study commissioned by the NPS (Graczyk, 1986), a 1974-1986 USGS National Stream Quality Accounting Network study (St. Croix Falls site only) (U.S. Environmental Protection Agency, 1996), a 1995-98 USGS National Water-Quality Assessment study (Stark and others, 1996 and 1999), and from 1997-99, a series of nutrient- and suspendedsediment-loading studies conducted in cooperation with the NPS and Wisconsin Department of Natural Resources (WDNR) (Fallon and McNellis, 2000; Lenz and others, 2001). Available water-quality data for the Danbury and St. Croix Falls monitoring sites are summarized in table 4. Values less than analytical detection limits were treated as zero for calculation of the statistics in table 4 .

\section{Field Water-Quality Constituents}

Field water-quality constituents, such as water temperature, specific conductance, $\mathrm{pH}$, and dissolved oxygen, were usually measured with the collection of USGS water-quality samples. Water temperatures of $0^{\circ}$ Celsius (C) along with ice cover were common in the winter. Maximum river temperatures exceeding $25^{\circ} \mathrm{C}$ were common in the summer. Water temperature values were slightly colder and less variable upstream at the Danbury site than at the St. Croix Falls site. Specific conductance values were lower and less variable at the Danbury site than at the St. Croix Falls site, averaging 122 and 169 microsiemens per centimeter at $25^{\circ} \mathrm{C}$, respectively. Total and bicarbonate alkalinity values were also lower at the Danbury site (averaging 64 and $52 \mathrm{mg} / \mathrm{L}$ ) than at the St. Croix Falls site (averaging 90 and 
Table 4. Summary of selected water-quality constituents analyzed at the Danbury and St. Croix Falls, Wis. monitoring sites on the St. Croix River, Wis. and Minn. [ $\mu \mathrm{s} / \mathrm{cm}$, microsiemens per centimeter; ${ }^{\circ} \mathrm{C}$, degrees Celsius; cols, colonies; $\mathrm{mL}$, milliliters; $\mathrm{mg} / \mathrm{L}$, milligrams per liter; dis., dissolved; $\mu \mathrm{g} / \mathrm{L}$, micrograms per liter; $\%$, percent]

\begin{tabular}{|c|c|c|c|c|c|c|c|c|c|c|c|c|c|c|}
\hline \multirow[b]{2}{*}{ Constituent } & \multicolumn{7}{|c|}{ St. Croix River near Danbury, Wis. } & \multicolumn{7}{|c|}{ St. Croix River at St. Croix Falls, Wis. } \\
\hline & $\stackrel{\bar{\varpi}}{\stackrel{\Xi}{\Sigma}}$ & 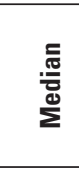 & $\begin{array}{l}\text { E } \\
\text { 言 } \\
\text { 离 } \\
\Sigma\end{array}$ & 志 & 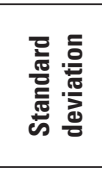 & 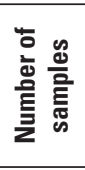 & 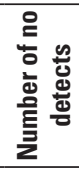 & $\sum_{\bar{\Phi}}^{\bar{\Phi}}$ & 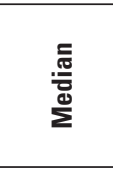 & 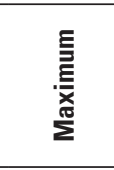 & 豆 & 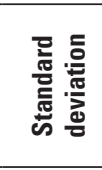 & 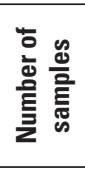 & 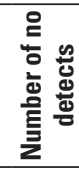 \\
\hline Specific conductance $(\mu \mathrm{s} / \mathrm{cm})$ & 122 & 12 & 228 & 48 & 31 & 210 & 0 & 169 & 169 & 295 & 7 & 43 & 269 & 0 \\
\hline $\mathrm{pH}$, water field (standard units) & 7.4 & 7.4 & 8.5 & 6.1 & 0.5 & 112 & 0 & 7.5 & 7.5 & 8.4 & 6.2 & 0.4 & 177 & 0 \\
\hline Temperature, water $\left({ }^{\circ} \mathrm{C}\right)$ & 9.4 & 6.5 & 26.0 & -0.1 & 8.8 & 214 & 0 & 10.4 & 9.0 & 27.4 & -0.1 & 9.2 & 272 & 0 \\
\hline Oxygen, dissolved (mg/L) & 10 & 10 & 15 & 5 & 2 & 105 & 0 & 10 & 10 & 26 & 5 & 3 & 148 & 0 \\
\hline Fecal coliform ${ }^{3},($ cols $/ 100 \mathrm{~mL})$ & 36 & 5 & 600 & $<2$ & 124 & 24 & $20^{1}$ & 46 & 21 & 420 & $<1$ & 73 & 86 & $47^{1}$ \\
\hline Fecal streptococcal ${ }^{4},(\mathrm{cols} / 100 \mathrm{~mL})$ & 176 & 56 & 770 & 3 & 239 & 24 & $5^{1}$ & 235 & 65 & 2000 & 1 & 447 & 82 & $24^{1}$ \\
\hline Hardness total $\left(\mathrm{mg} / \mathrm{L}\right.$ as $\left.\mathrm{CaCO}_{3}\right)$ & 57 & 58 & 81 & 26 & 12 & 110 & 0 & 79 & 81 & 120 & 26 & 18 & 176 & 0 \\
\hline Calcium, dis. $(\mathrm{mg} / \mathrm{L}$ as $\mathrm{Ca})$ & 15.5 & 16 & 22 & 7 & 3 & 109 & 0 & 21 & 21 & 40 & 7 & 5 & 174 & 0 \\
\hline Magnesium, dis. (mg/L as $\mathrm{Mg}$ ) & 4.4 & 4.5 & 6.3 & 1.7 & 0.9 & 109 & 0 & 6.6 & 6.8 & 10.0 & 1.8 & 1.5 & 174 & 0 \\
\hline Sodium, dis. $(\mathrm{mg} / \mathrm{L}$ as $\mathrm{Na})$ & 2.3 & 2.3 & 3.3 & 1.2 & 0.4 & 108 & 0 & 3.1 & 3.2 & 9.2 & 1.5 & 0.8 & 173 & 0 \\
\hline Potassium, dis. (mg/L as $\mathrm{K})$ & 0.6 & 0.6 & 1.3 & 0.3 & 0.2 & 108 & 0 & 1.1 & 1.0 & 5.2 & $<0.1$ & 0.5 & 173 & 1 \\
\hline $\begin{array}{l}\text { Bicarbonate, dis. field } \\
\left(\mathrm{mg} / \mathrm{L} \text { as } \mathrm{HCO}_{3}\right)\end{array}$ & 64 & 68 & 106 & 22 & 17 & 92 & 0 & 90 & 93 & 130 & 30 & 22 & 114 & 0 \\
\hline $\begin{array}{l}\text { Alkalinity, dis. field } \\
\left(\mathrm{mg} / \mathrm{L} \text { as } \mathrm{CaCO}_{3}\right)\end{array}$ & 52 & 56 & 87 & 18 & 14 & 98 & 0 & 73 & 76 & 110 & 22 & 18 & 144 & 0 \\
\hline Sulfate, dis. $\left(\mathrm{mg} / \mathrm{L}\right.$ as $\left.\mathrm{SO}_{4}\right)$ & 3.8 & 3.4 & 10.0 & 1.5 & 1.5 & 112 & 0 & 5.1 & 5.1 & 13.0 & 0.1 & 2.2 & 177 & 0 \\
\hline Chloride, dis. (mg/L as $\mathrm{Cl})$ & 2.3 & 2.2 & 7.8 & $<0.1$ & 0.9 & 112 & 1 & 3.8 & 3.3 & 17.1 & 1.0 & 2.0 & 177 & 0 \\
\hline Fluoride, dis. (mg/L as F) & $<0.1$ & $<0.1$ & 0.3 & $<0.1$ & 0.05 & 109 & 91 & $<0.1$ & $<0.1$ & 2.4 & $<0.1$ & 0.3 & 176 & 100 \\
\hline Silica, dis. $\left(\mathrm{mg} / \mathrm{L}\right.$ as $\left.\mathrm{SiO}_{2}\right)$ & 11.3 & 11.0 & 17.0 & 7.7 & 2.3 & 108 & 0 & 11.6 & 11 & 27 & 4.8 & 3.3 & 173 & 0 \\
\hline Solids, dis. (mg/L) & 73 & 75 & 136 & 36 & 16 & 106 & 0 & 96 & 98 & 153 & 37 & 20 & 173 & 0 \\
\hline Nitrogen, total (mg/L as N) & 0.5 & 0.5 & 1.2 & 0.2 & 0.2 & 79 & 0 & 0.8 & 0.7 & 2.6 & 0.2 & 0.3 & 165 & 0 \\
\hline Nitrogen, dis. $(\mathrm{mg} / \mathrm{L}$ as $\mathrm{N})$ & 0.4 & 0.3 & 1.1 & 0.05 & 0.2 & 56 & 0 & 0.6 & 0.6 & 1.8 & 0.33 & 0.2 & 91 & 0 \\
\hline $\begin{array}{l}\text { Nitrogen, } \mathrm{NO}_{2}+\mathrm{NO}_{3} \text { dis. } \\
(\mathrm{mg} / \mathrm{L} \text { as } \mathrm{N})\end{array}$ & 0.1 & 0.09 & 0.38 & $<0.05$ & 0.08 & 80 & 23 & 0.22 & 0.15 & 0.87 & 0.01 & 0.15 & 121 & 0 \\
\hline $\begin{array}{l}\text { Nitrogen, ammonia dis. } \\
(\mathrm{mg} / \mathrm{L} \text { as } \mathrm{N})\end{array}$ & 0.02 & 0.02 & 0.09 & $<0.04$ & 0.02 & 107 & 49 & 0.05 & 0.03 & 0.37 & $<0.01$ & 0.06 & 119 & 24 \\
\hline $\begin{array}{l}\text { Nitrogen, ammonia + organic total } \\
(\mathrm{mg} / \mathrm{L} \text { as } \mathrm{N})\end{array}$ & 0.4 & 0.4 & 1.1 & $<0.1$ & 0.2 & 109 & 3 & 0.6 & 0.5 & 3.2 & 0.13 & 0.4 & 172 & 0 \\
\hline $\begin{array}{l}\text { Nitrogen, ammonia + organic dis. } \\
(\mathrm{mg} / \mathrm{L} \text { as } \mathrm{N})\end{array}$ & 0.3 & 0.3 & 1.5 & $<0.1$ & 0.2 & 80 & 10 & 0.5 & 0.4 & 1.2 & 0.07 & 0.2 & 117 & 0 \\
\hline Phosphorus, total (mg/L as $\mathrm{P}$ ) & 0.02 & 0.02 & 0.08 & $<0.008$ & 0.02 & 109 & 24 & 0.04 & 0.04 & 0.20 & $<0.01$ & 0.04 & 177 & 11 \\
\hline Phosphorus, dis. (mg/L as $\mathrm{P})$ & $<0.01$ & $<0.01$ & 0.06 & $<0.01$ & 0.01 & 106 & 45 & 0.02 & 0.01 & 0.17 & $<0.004$ & 0.02 & 141 & 37 \\
\hline Phosphorus-ortho, dis. (mg/L as $\mathrm{P}$ ) & $<0.01$ & $<0.01$ & 0.026 & $<0.01$ & 0.007 & 80 & 59 & $<0.010$ & $<0.010$ & 0.257 & $<0.010$ & 0.04 & 98 & 51 \\
\hline Iron, dis. $^{2}(\mu \mathrm{g} / \mathrm{L}$ as $\mathrm{Fe})$ & 227 & 200 & 790 & 40 & 132 & 91 & 0 & 301 & 280 & 940 & 20 & 193 & 115 & 0 \\
\hline Lead, total ${ }^{2}(\mu \mathrm{g} / \mathrm{L}$ as $\mathrm{Pb})$ & 9.3 & 6.0 & 24 & $<1.0$ & 8.4 & 9 & 1 & 9.8 & 7.0 & 63 & $<1.0$ & 11.8 & 32 & 1 \\
\hline Manganese, dis. ${ }^{2}(\mu \mathrm{g} / \mathrm{L}$ as $\mathrm{Mn})$ & 18 & 12 & 270 & 5.8 & 29 & 91 & 0 & 32 & 24 & 223 & 1.2 & 29 & 115 & 0 \\
\hline Nickel, dis. ${ }^{2}(\mu \mathrm{g} / \mathrm{L}$ as $\mathrm{Ni})$ & 5.2 & 3.0 & 16 & $<1.0$ & 5.6 & 8 & 1 & 2.8 & 1.0 & 19 & $<1.0$ & 4.6 & 28 & 8 \\
\hline Selenium, total $^{2}(\mu \mathrm{g} / \mathrm{L}$ as Se$)$ & $<1$ & $<1$ & $<1$ & $<1$ & 0 & 9 & 9 & $<1$ & $<1$ & 1 & $<1$ & 0 & 31 & 22 \\
\hline Zinc, total $^{2}(\mu \mathrm{g} / \mathrm{L}$ as $\mathrm{Zn})$ & 14 & 10 & 20 & $<10$ & 5 & 9 & 2 & 44 & 20 & 380 & $<10$ & 88 & 31 & 14 \\
\hline Carbon, organic, dis. (mg/L as $\mathrm{C}$ ) & 7.1 & 6.1 & 20 & 2.4 & 3.7 & 78 & 0 & 8.4 & 7.7 & 20 & 1.5 & 3.7 & 85 & 0 \\
\hline $\begin{array}{l}\text { Carbon, organic suspended, total } \\
(\mathrm{mg} / \mathrm{L} \text { as } \mathrm{C})\end{array}$ & 0.5 & 0.4 & 2.2 & 0.1 & 0.4 & 78 & 0 & 8.8 & 8.1 & 21.3 & 1.1 & 4.1 & 109 & 0 \\
\hline Sediment, suspended $(\mathrm{mg} / \mathrm{L})$ & 9 & 5 & 94 & 1 & 14 & 111 & 0 & 10 & 6 & 85 & 1 & 13 & 165 & 0 \\
\hline $\begin{array}{l}\text { Sediment, suspended, } \\
\% \text { finer than } 0.062 \mathrm{~mm}\end{array}$ & 71 & 76 & 100 & 4 & 23 & 78 & 0 & 84 & 89 & 100 & 0 & 20 & 125 & 0 \\
\hline
\end{tabular}

${ }^{1}$ Values below detect determined using most probable number method (Cochran, 1950); ${ }^{2}$ May be positively biased from sample handling prior to 1992 ;

${ }^{3}$ Values determined using mFC MF agar method (Britton and Greeson, 1987); ${ }^{4}$ Values determined using membrane filter method (Greeson and others, 1977) 


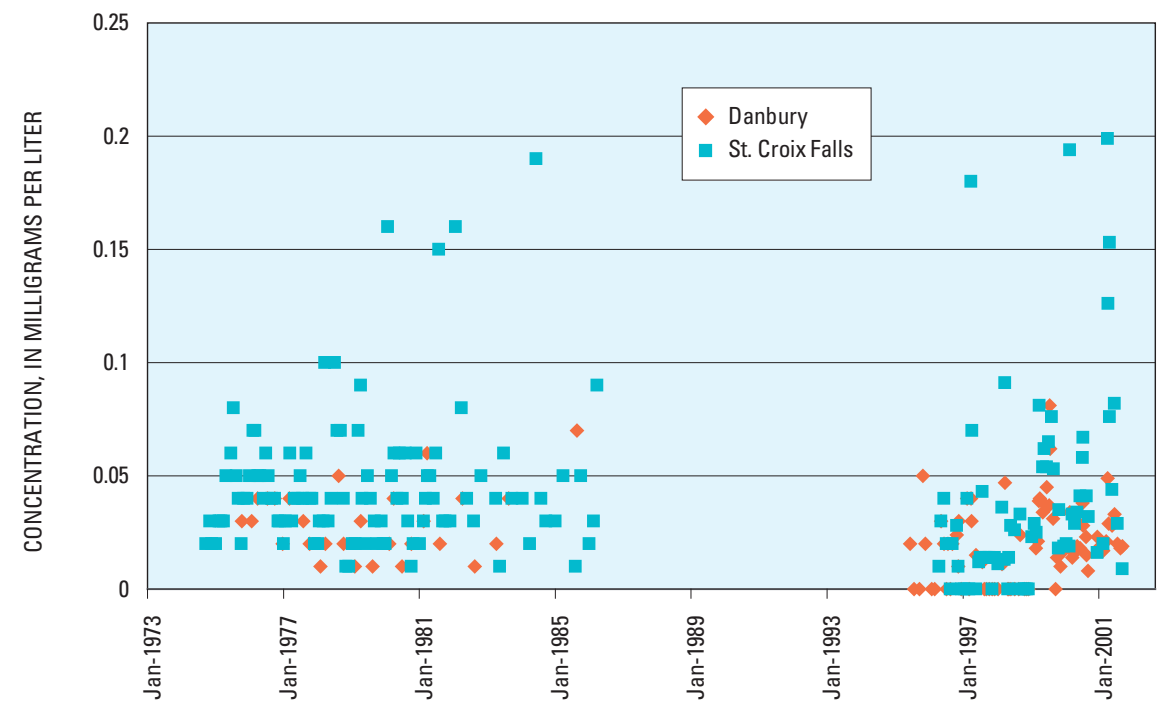

Figure 3. Total phosphorus concentrations at Danbury and St. Croix Falls, Wis. on the St. Croix River, Wis. and Minn. [Values less than detection limits were plotted at zero.]

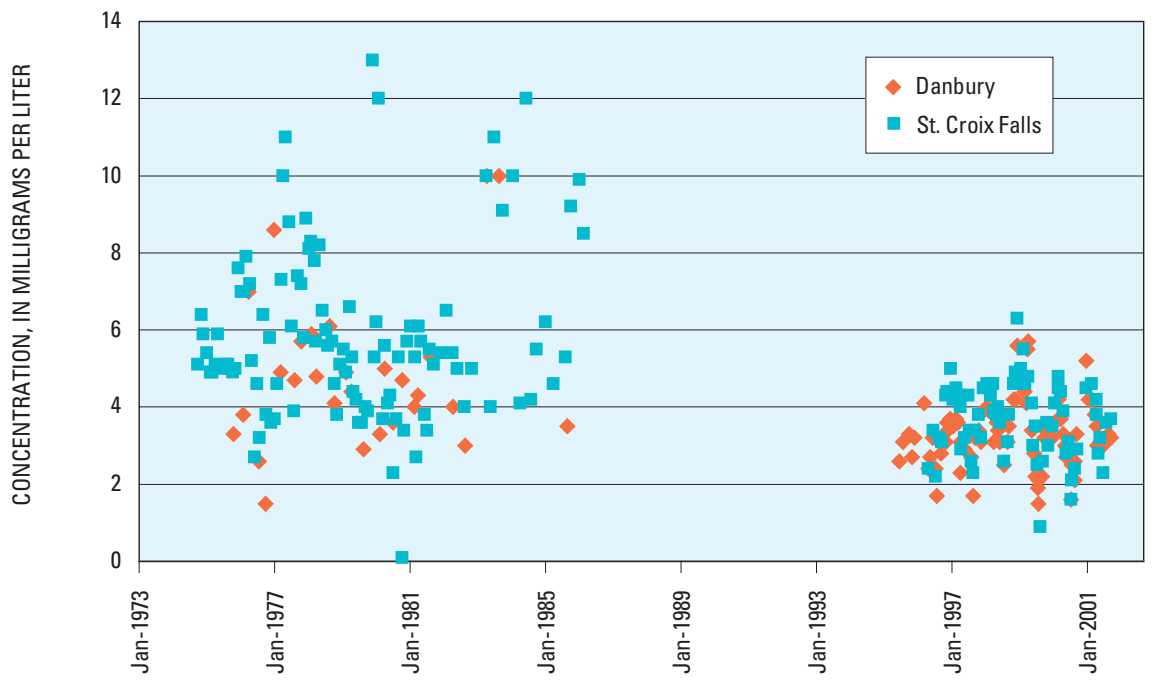

Figure 4. Dissolved sulfate concentrations at Danbury and St. Croix Falls, Wis. on the St. Croix River, Wis. and Minn.

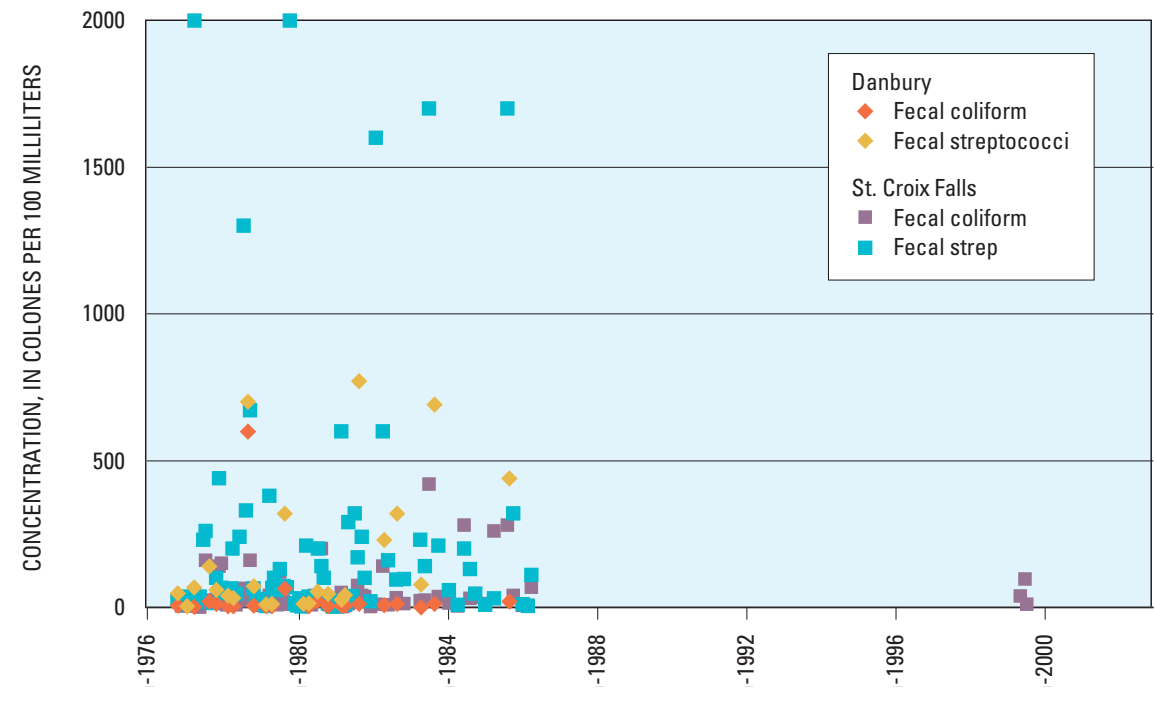

Figure 5. Bacteria concentrations at Danbury and St. Croix Falls, Wis. on the St. Croix River, Wis. and Minn. [Bacteria sample methods after Britton and Greeson, 1987.]
$73 \mathrm{mg} / \mathrm{L})$. Samples at both sites had $\mathrm{pH}$ values ranging from 6.1 to 8.0 (in standard units).

\section{Nutrients and Suspended Sediments}

Six suspended-sediment samples were collected at the Danbury site from 1964 to 1966. Suspended-sediment and nutrient samples were collected quarterly from 1976 to 1981, twice a year in 1982 and 1983, and monthly and during runoff events from 1995 to 2001. Two nitrate samples were collected in November 1966 at the St. Croix Falls site. Suspended-sediment and nutrient samples were collected monthly in 197581 , bi-monthly in 1982 , monthly in spring and summer of 1983, quarterly from 1984 to 1986, twice in 1994, once in 1995, and monthly and during several runoff events from 1996 to 2001.

Nutrient and suspended-sediment concentration data were generally lower and less variable upstream at the Danbury site than at the St.

Croix Falls site. Mean total phosphorus and total nitrogen concentrations at the Danbury site were 0.02 and 0.5 milligrams per liter $(\mathrm{mg} / \mathrm{L})$, respectively, and mean concentrations at the St. Croix Falls site were 0.04 and $0.8 \mathrm{mg} / \mathrm{L}$, respectively. The variability in total phosphorus concentrations at and between sites is shown in figure 3. Other nutrient data have similar variability. Mean suspended-sediment concentrations were $9 \mathrm{mg} / \mathrm{L}$ at the Danbury site and 10 $\mathrm{mg} / \mathrm{L}$ at the St. Croix Falls site. The mean percent suspended sediment finer than 0.062 millimeter was 71 percent at the Danbury site compared to 84 percent at the St. Croix Falls site.

In an effort to account for the effects of variable flow on concentrations, flow-weighted concentrations of all nutrients and suspended sediment were calculated by water year at both sites. No trends were detected in statistical analysis of the flow-weighted data. The runoff-event-driven nature of nutrient and suspended-sediment loading in the St. Croix River Basin results in highly variable concentrations and loading rates (Lenz and others, 2001). Detection of trends in a basin with such variability is difficult without consistent, long-term data or major changes in water quality.

\section{Major lons}

Major ion samples were collected at the Danbury site once in 1966, once in 1968, quarterly from 1976 to 1981, twice a year in 1982 and 1983 , once in 1985, and monthly and during runoff events from 1996 to 2001. At the St. Croix 


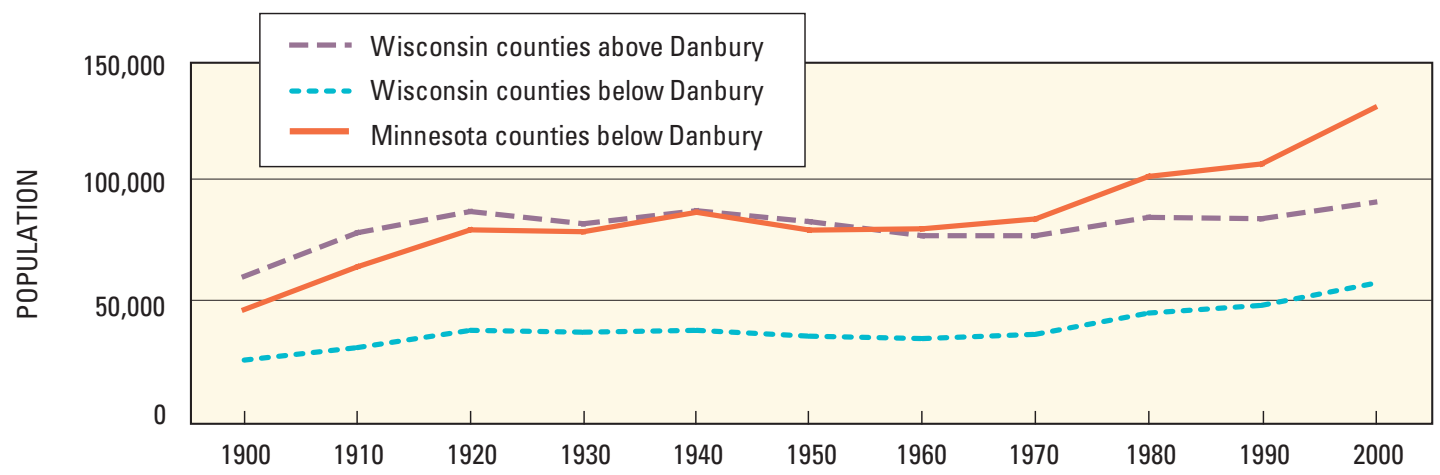

Figure 6. Population estimates for Wisconsin and Minnesota counties entirely or partially within the St. Croix Basin above St. Croix Falls, Wis. (U.S. Census Bureau, 2002).

Falls site, major ion samples were collected once in 1966, once in 1968, monthly in water years 1975-81, quarterly from 1982 to 1985 , twice in 1986 , and monthly and during several runoff events from 1996 to 2001.

Patterns in the major ion concentration data were similar to those for nutrient and suspended-sediment concentration data; that is, there were generally lower and less variable concentrations upstream at the Danbury site than at the St. Croix Falls site. Sulfate was the only ion that had a statistically significant change in concentration over time. Sulfate concentrations were greater than $10 \mathrm{mg} / \mathrm{L}$ in many samples from the late $1970 \mathrm{~s}$ and early 1980s, but all concentrations in samples from 1996 to 2001 were less than $7 \mathrm{mg} / \mathrm{L}$ (fig. 4).

\section{Metals}

Metals in the water column were sampled annually from 1975 to 1983 at the Danbury site and quarterly from 1975 to 1986 at the St. Croix Falls site. Compared to examining concentrations in the water column, examination of streambed sediments can be more appropriate for detecting changes in metal levels in rivers. Brigham (2002) conducted detailed analysis of trace elements, including metals, in streambed sediments within the St. Croix River in 2000. He concluded that there did not appear to be large anthropogenic contributions above the background geochemical and atmospherically deposited levels. However, the study found possible occurrences of low-level anthropogenic contributions of several trace elements downstream of a few of the larger cities in the basin.

\section{Bacteria}

Fecal coliform and fecal streptococci samples were collected quarterly from 1976 to 1983 and once in 1985 at the Danbury site. Samples were collected monthly from 1975 to 1982, quarterly from 1983 to 1986, and three times during the summer of 1999 at the St. Croix Falls site. Bacteria concentrations at both sites ranged from less than 1 to 2,000 colonies per 100 milliliters and had substantial scatter with no distinct spatial or temporal patterns evident (fig. 5). There was no trend in the frequency of high bacteria counts.

\section{Pesticides}


16 percent above Danbury and 98 percent between Danbury and St. Croix Falls from 1910 to 2000. Substantial land-use changes are likely associated with the population increase.

\section{Summary and Conclusions}

Trend analysis of long-term streamflow data from streamflow-gaging stations on the St. Croix River near Danbury (85 years of record) and at St. Croix Falls (95 years of record) indicates that annual peaks, annual mean flows, and low flows have remained relatively stable at the Danbury (upstream) site while increasing by 0.45 to 0.55 percent per year at the St. Croix Falls (downstream) site.

The St. Croix River sites are in such close proximity that climate should similarly affect flow at both sites. The trends of increased flow between Danbury and St. Croix Falls may be related to factors other than climate, such as hydropower operation, population growth, changes in agricultural practices, or changes in land use. Additional study would be needed to substantiate and quantify such relations.

Water-quality data collected at these two sites from 1964 to 2001 have high temporal variation due to the runoff-eventdriven nature of the St. Croix River and are often limited in extent by the data-collection needs of previous studies. Nutrient, suspended-sediment, and major ion concentrations were generally lower and less variable at the Danbury site than at the St. Croix Falls site. However, disparate sampling periods and strategies could cause possible biases in the comparison of water quality between sites. The absence of consistent longterm water-quality data made statistical trend analysis of waterquality data impractical.

Starting in 1970, population has greatly increased in the basin, with the counties in Minnesota below Danbury showing the largest increase.

\section{References Cited}

Brigham, M.E., 2002, Elemental chemistry of streambed sediments of the St. Croix River Basin, 2000: U.S. Geological Survey WaterResources Investigation Report 02-4087.

Britton, L.J., and Greeson, P.E., eds., 1987, Methods for collection and analysis of aquatic biological and microbiological samples: U.S. Geological Survey Techniques of Water-Resources Investigations, book 5, chap. A4, variously paginated.

Cochran, W.G., 1950, Estimation of Bacterial Density by means of the most probable number: Biometrics, vol. 6, p. 105-116.

Conover, W.J.,1971, Practical nonparametric statistics. New York: John Wiley \& Sons. p. 97-104.

Fallon, J.D., and McNellis, R.P., 2000, Nutrients and suspended sediment in snowmelt runoff from the Upper Mississippi River Basin, Minnesota and Wisconsin, 1997: U.S. Geological Survey WaterResources Investigations Report 99-4165, 23 p.

Gebert, W.A., and Krug, W.R., 1996, Streamflow trends in Wisconsin's Driftless Area: Journal of American Water Resources Association, vol. 32, no. 4, p. 733-744.
Graczyk, D.J., 1986, Water quality in the St. Croix National Scenic Riverway, Wisconsin: U.S. Geological Survey Water-Resources Investigation Report 85-4319, 48 p.

Greeson, P.E., Ehlke, T.A. Irwin, G.A., Lium, B.W., and Slack, K.V., 1977, Methods for collection and analysis of aquatic biological and microbiological samples: U.S. Geological Survey Techniques of Water-Resources Investigations, book 5, chap. A4, 336 p.

Hunt, R.J., and Steuer, J.J., 2001, Evaluating the effects of urbanization and land-use planning using ground-water and surface-water models: U.S. Geological Survey Fact Sheet FS-102-01, 4 p.

Kendall, M.G., 1975, Rank correlation methods, London: Charles Griffin \& Company, Ltd., 4th ed., 202 p.

Lenz, B.N., Robertson, D.M., Fallon, J.D., and Ferrin, R., 2001, Nutrient and suspended-sediment concentrations and loads and benthicinvertebrate data for tributaries to the St. Croix River, Wisconsin and Minnesota, 1997-99: U.S. Geological Survey Water-Resources Investigation Report 01-4162, 57 p.

Potter, K.W., 1991, Hydrologic impacts of changing land management practices in a moderate-sized agricultural catchment: Water Resources Research, vol. 27, no 5, p. 845-855.

Seaber, R.R., Kapinos, F.P., and Knapp, G.L., 1986, Hydrologic unit maps: U.S. Geological Survey Water-Supply Paper 2294, 63 p.

Stark, J.R., Andrews, J.W., Fallon, J.D., Fong, A.L., Goldstein, R.M., Hanson, P.E., Kroening, S.E., and Lee, K.E., 1996, Water-quality assessment of part of the Upper Mississippi River Basin, Minnesota and Wisconsin, environmental settings and study design: U.S. Geological Survey Water-Resources Investigations Report 96-4098, $62 \mathrm{p}$.

Stark, J.R., Fallon, J.D., Fong, A.L., Goldstein, R.M., Hanson, P.E., Kroening, S.E., and Lee, K.E., 1999, Water-quality assessment of part of the Upper Mississippi River Basin, Minnesota and Wisconsin, design and implementation of water-quality studies, 1995-1998: U.S. Geological Survey Water-Resources Investigations Report 99-4135, 85 p.

U.S. Census Bureau, 2002, U.S. Census Bureau, accessed July 18, 2002, at URL http://www.census.gov.

U.S. Census Bureau, 1995, The population of states and counties of the United States: 1790 to 1990, National Technical Information Service microcomputer diskette PB96500525, $236 \mathrm{p}$.

U.S. Environmental Protection Agency, 1996, National Waters Indicators Report: Washington, D.C., EPA 841-R-96-002, 25 p.

\section{For Additional Information: \\ U.S. Geological Survey, \\ Information Services \\ Box 25286, Denver Federal Center \\ Denver, CO 80225}

Telephone: 1-888-ASK-USGS

World Wide Web: http://www.usgs.gov/

By Bernard N. Lenz

In cooperation with the National Park Service and the Joint Water Quality Commission of Danbury and St. Croix Chippewa Indians of Wisconsin. 